\title{
ANALISIS FAKTOR YANG MEMPENGARUHI PRESTASI BELAJAR MATA PELAJARAN DI SMP NEGERI 03 KEPANJEN
}

\author{
Kardisius Agot \\ e-mail : bagetghancarut@gmail.com \\ Rusno \\ e-mail:rusno@unikama.ac.id \\ Walipah \\ e-mail:walipah@unikama.ac.id
}

(Program Studi Pendidikan Ekonomi, Fakultas Ekonomika dan Bisnis, Universitas Kanjuruhan, Malang)

\begin{abstract}
The purpose of this study is 1. to find out and analyze what factors influence the success of social studies learning achievement in students of SMP Negeri 03 Kepanjen Malang Regency.2. To find out and analyze the dominant factors that influence the learning achievement of social studies subjects in SMP Negeri 03 Kepanjen. The population in this study were students of class VII in SMP Negeri 03 Kepanjen whose IPS scores were less than KKM, totaling 186 students. And the sample is 48 students. The data collection technique used was Questionnaire Data obtained were analyzed by factor analysis techniques. This type of research uses factor analysis using Bartlett's lest of Sphericity. Based on the results of the study showed that there were 15 (fifteen) learning achievement factors formed, these factors were as follows: (1) family environmental factors, $17.21 \%$ (2) $7.80 \%$ material mastery factors. (3) class atmosphere factors, $6.80 \%$. (4) learning source factors are $5.95 \%$. (5) student activeness factor is $4.68 \%$. (6) learning interest factors are $4.48 \%$. (7) school environment factors, $3.92 \%$. (8) physiological factors of students, 3.68\%. (9) learning method factors $3.39 \%$. (10) community environmental factors $3.21 \%$. (11) the teacher discipline factor is $2.99 \%$. (12) the method of teaching methods of teachers is $2.85 \%$. (13) student readiness factor $2.68 \%$. (14) learning facility factors $2.56 \%$ (15) curriculum factors $2.35 \%$. The factor which gave the biggest contribution was the family environment factor, which was $17.21 \%$. The smallest contribution is given by the curriculum factor which is $2.35 \%$.
\end{abstract}

Keywords : Factors, social studies learning achievement, junior high students

\begin{abstract}
Abstrak: Tujuan penelitian ini adalah 1. untuk mengetahui dan menganalisa faktor apa yang mempengaruhi keberhasilan prestasi belajar mata pelajaran IPS pada siswa SMP Negeri 03 Kepanjen Kabupaten Malang.2. Untuk mengetahui dan menganalisa faktor dominan yang mempengaruhi prestasi belajar mata pelajaran IPS pada siswa SMP Negeri 03 Kepanjen. Populasi dalam penelitian ini adalah siswa kelas VII di SMP Negeri 03 Kepanjen yang nilai IPS nya kurang dari KKM yaitu berjumlah 186 siswa. Dan sampel nya berjumlah 48 siswa. Teknik pengumpulan data digunakan adalah Angket Data yang diperoleh dianalisis dengan tehnik analisis faktor. Jenis Penelitian menggunakan Analisis faktor dengan mengggunakan Bartlett's lest of Sphericity. Berdasarkan hasil penelitian menunjukan bahwa terdapat 15 (lima belas) faktor prestasi belajar yang terbentuk, faktor-faktor tersebut adalah sebagai berikut: (1) faktor lingkungan keluarga,17,21\% (2) faktor penguasaan materi $7,80 \%$. (3) faktor suasana kelas,6,80\%. (4) faktor sumber belajar 5,95\%. (5) faktor keaktifan siswa 4,68\%. (6) faktor minat belajar 4,48\%. (7) faktor lingkungan sekolah, 3,92\%. (8) faktor fisiologis siswa,3,68\%. (9) faktor metode belajar 3,39\%. (10) faktor lingkungan masyarakat 3,21\%. (11) faktor kedisiplinan guru 2,99\%. (12) faktor metode mengajar guru 2,85\%. (13) faktor kesiapan siswa 2,68\%. (14) faktor fasilitas belajar 2,56\% (15) faktor kurikulum 2,35\%. Faktor yang memberi kontribusi paling besar adalah faktor lingkungan keluarga yaitu sebesar 17,21\% . kontribusi terkecil diberikan oleh faktor kurikulum yaitu sebesar 2,35\%.
\end{abstract}

Kata kunci : Faktor-faktor, prestasi belajar IPS, Siswa SMP 


\section{PENDAHULUAN}

Pendidikan merupakan bagian yang tak terpisahkan dari kehidupan manusia dan juga merupakan kunci dalam keberhasilan pembangunan. Berhasil tidaknya pembangunan nasional ditentukan oleh kualitas Sumber Daya Manusia (SDM) itu sendiri. Sumber daya manusia yang berkualitas merupakan modal dasar dalam persaingan di era globalisasi sekarang ini. Hal ini dikarenakan beberapa hal antara lain jumlah penduduk semakin besar sehingga persaingan semakin ketat, berkurangnya sumber daya alam serta semakin majunya teknologi (www. Human Development Indonesia.Com). Menurut UU No. 20 Tahun 2003 dalam bab II pasal 3 yang menyatakan bahwa pendidikan nasional menyatakan bahwa, "Pendidikan Nasional berfungsi mengembangkan kemampuan dan membentuk watak serta peradaban bangsa yang bermartabat dalam rangka mencerdaskan kehidupan bangsa, bertujuan untuk berkembangnya potensi peserta pendidik agar menjadi manusia yang beriman dan bertakwa kepada Tuhan Yang Maha Esa, berakhlak mulia, sehat, berilmu, cakap, kreatif, dan mandiri menjadi warga Negara yang demokratis serta bertanggung jawab".

Menurut Arikunto (2009) prestasi belajar merupakan hasil yang diperoleh karena adanya aktivitas belajar mengajar yang telah dilakukan. Prestasi belajar merupakan hal yang tidak dapat dipisahkan dari kegiatan belajar, karena kegiatan belajar merupakan proses sedangkan prestasi belajar merupakan hasil dari proses belajar. Menurut Syah (2010) prestasi belajar dipengaruhi oleh beberapa faktor yang dibedakan antara faktor internal dan faktor eksternal faktor internal meliputi faktor fisiologis dan psikologis siswa. Faktor fisiologis seperti pengelihatan, pendengaran, struktur tubuh, dan sebagainya sedangkan faktor psikologis seperti kecerdasan, sikap, bakat, minat dan motivasi. Trianto (2010) Menyatakan bahwa ilmu pengetahuan sosial (IPS) merupakan intregrasi dari berbagai cabang ilmu-ilmu sosial, seperti sosiologi, sejarah, geografi, ekonomi, politik, hukum, dan budaya ilmu pengetahuan sosial dirumuskan atas dasar realitas dan fenomena sosial masyarakat yang diwujudkan dalam satu pendekatan intersipliner dari aspek dan ilmu cabang-cabang ilmu sosial

SMP Negeri 03 Kepanjen pada mata pelajaran IPS merupakan mata pelajaran yang tidak dapat mencapai KKM dengan optimal. Padahal standar ketuntasan belajar yang diharapkan adalah 75. Dalam proses pembelajaran, siswa berhasil belajar apabila telah mencapai nilai rata-rata diatas KKM. Kondisi ini mencerminkan bahwa proses pembelajaran IPS di SMP Negeri 03 Kepanjen pada kelas VII belum berhasil dengan maksimal, karena prestasi yang dicapai oleh siswa masih sangat rendah.

\section{TINJAUAN PUSTAKA}

Pada penelitian ini menggunakan beberapa penelitian terdahulu yang pernah dilakukan dan dapat menjadi tinjauan studi, yaitu sebagai berikut :

1. Dana rafiti suwardi (2012) yang berjudul : Faktor-faktor yang mempengaruhi hasil belajar siswa kompetensi dasar ayat jurnal penyesuaian mata pelajaran Akuntansi XI IPS di SMA NEGERI BAE KUDUS

2. Yuli widiastuti (2013) yang berjudul : Analisis faktor yang mempengaruhi prestasi belajar Akuntansi di SMA NEGERI 1 KELAS XI-IPS

Menurut pandangan Gagne dalam Damyati dan Mujiono (2009) mengemukakan "Belajar adalah serangkaian proses kongnitif yang mengubah sifat stimulasi lingkungan, melewati pengolahan informasi, menjadi kapabilitas baru". Istilah kapabilitas diartikan sebagai perubahan tingkah laku akibat kegiatan belajar mengajar. Slameto (2008: 2) "Ada tiga unsur pokok tentang pengertian belajar sebagai berikut: 
Adanya perubahan perilaku. Adanya proses pengalaman perubahan perilaku itu terjadi karena didahului oleh proses pengalaman. Lamanya waktu perubahan perilaku yang dimiliki oleh pembelajar yang berbentuk perubahan kongnitif, afektif, psikomotorik. Menurut Dimyati dan Mujiono (2009) prinsip-prinsip belajar meliputi: (1) perhatian dan motivasi, (2) keaktifan, (3) keterlibatan langsung atau berpengalaman, (4) pengulangan, (5) tantangan, (6) balikan atau penguatan, (7) perbedaan individual. Sedangkan menurut menurut Syah (2010) prestasi belajar dipengaruhi oleh beberapa faktor yang dibedakan antara faktor internal dan faktor eksternal faktor internal meliputi faktor fsikologis dan fsikologis siswa faktor fisiologis siswa seperti penglihatan, pendengaran, struktur tubuh, dan sebagainya.

Sugiyono, (2015:19) mengatakan bahwa kerangka berpikir merupakan model konseptual tenntang bagaimana teori berhubungan dengan berbagai faktor yang telah diidentifikasi sebagai masalah yang penting. Kerangka berpikir yang baik akan menjelaskan secara teoritis peraturan antara variabel yang akan diteliti. Adapun hipotesis dalam penelitian ini yaitu : terdapat pengaruh faktor internal dan eksternal yang mempengaruhi prestasi belajar siswa di SMP Negeri 03 Kepanjen

\section{METODE}

Metode penelitian yang digunakan dalam penelitian ini adalah metode deskriptif kualitatif karena dalam penelitian ini, peneliti ingin menganalisis bagaimana penerapan dengan analisis faktor yang mempengaruhi keberhasilan prestasi belajar mata pelajaran IPS Terpadu yang digunakan pada pembelajaran. Menurut Morgono (2010) rancangan penelitian adalah alur kegiatan peneliti dalam memecahkan masalah, disusun secara matang dan cermat sehingga nantinya akan sangat membantu peneliti maupun orang yang membaca hasil penelitiannya dalam memahami masalah serta cara mengatasinya.

Ruang lingkup dalam penelitian ini adalah Penelitian memberikan batasan sehingga penelitian ini bisa fokus serta tidak melebar. Antara lain : Populasi dalam penelitian ini yaitu semua siswa kelas VII (tujuh) mata pelajaran IPS SMP Negeri 03 Kepanjen, Analisis faktor yang mempengaruhi prestasi belajar, Lokasi penelitian di SMP Negeri 03 Kepanjen (JL. Sukoharjo. Kepanjen Malang, Jawa Timur 65163). Seperti menurut Sugiyono (2014) yang menjelaskan bahwa "Populasi merupakan suatu wilayah generalisasi yang terdiri atas obyek/subyek yang dimana mempunyai sebuah kualitas dan sebuah karakteristik tertentu yang akan diterapkan oleh peneliti untuk dipelajari.

\section{PEMBAHASAN}

Analisis data dilakukan dengan menggunakan analisis faktor. Analisis faktor ini dilakukan untuk mengungkap faktor-faktor yang mempengaruhi keberhasilan prestasi belajar mata pelajaran IPS di SMP Negeri 03 Kepanjen Kabupaten Malang. Dalam analisis ini dilakukan dengan 4 tahap sebab, ada beberapa faktor yang harus dikeluarkan dari setiap tahap sampai dengan sudah tidak ada item faktor yang tereliminasi. Analisis ini digunakan untuk mengetahui besarnya KMO Communalities, Anti Image Correlation, dan Total Variance Explained.

\section{Analisis tahap 1}

KMO (Kaiser Meyer Olklin), yaitu angka indeks yang digunakan untuk menguji ketepatan analisis faktor, Nampak bahwa koefisien KMO sebesar 0,531 dan lebih besar dari 0,50 sehingga dapat dikatakan bahwa hasil analisis ini sudah tepat digunakan. Karena nilai KMO lebih dari 0,5 maka 
analisis faktor ini sudah tepat. Communalities, dimana nampak bahwa semua faktor nilai nya lebih besar dari 0,50 sehingga dapat dikatakan faktor yang bersangkutan cukup efektif. Anti Image Correlation, terdapat 10 faktor yang nilainya di bawah 0,05 yaitu faktor X2, X8, X10, X22, X24, X25, X27, X28, X29, X31 sehingga harus dikeluarkan dari model. Total Variance Explained, dapat diketahui bahwa nilai eigenvalue yang lebih besar dari 1,00 berjumlah 18 (delapan belas) buah sehingga dalam hal ini

\section{Analisis tahap 2}

Hasil pengujian ulang tahap 2, setelah ke-5 faktor tersebut dikeluarkan dari model dan dilakukan pengujian ulang. Nampak bahwa nilai KMO adalah 0,559 dan lebih besar dari 0,50 sehingga dapat dikatakan bahwa hasil analisis ini sudah tepat digunakan. Karena nilai KMO lebih dari 0,5 maka analisis faktor ini sudah tepat. Communalities, dimana nampak bahwa semua faktor nilainya lebih besar dari 0,50 sehingga dapat dikatakan bahwa faktor yang bersangkutan cukup efektif. Total Variance Explained, dapat dilihat bahwa nilai eigenvalues yang lebih dari 1,00 berjumlah 17 buah faktor sehingga dalam hal ini akan terdapat 17 komponen yang akan dibentuk oleh faktor yang akan dimasukkan ke dalam model untuk membentuk variabel. Rotated Component Matrix, dapat diketahui bahwa terdapat 17 kelompok faktor yang nantinya akan membentuk variabel yang mempengaruhi keberhasilan prestasi belajar mata pelajaran IPS kelas VII di SMP Negeri 03 Kepanjen. Nampak bahwa terdapat 9 (tiga) faktor yang gugur dan harus dikeluarkan dari model yaitu faktor X32 X35, X35, X36, X37, X38, X40, X42, X45

\section{Analisis tahap 3}

Hasil pengujian ulang tahap 3, setelah ke-3 faktor tersebut dikeluarkan dari model dan dilakukan pengujian ulang. Nampak bahwa nilai KMO adalah 0,594 dan lebih besar dari 0,50 sehingga dapat dikatakan bahwa analisis sudah tepat digunakan. Karena nilai $\mathrm{KMO}$, lebih dari 0,5 maka analisis faktor ini sudah tepat Communalities dimana nampak bahwa semua faktor nilainya lebih besar dari 0,50 sehingga dapat dikatakan bahwa faktor yang bersangkutan cukup efektif.

Total Variance Explained, dapat dilihat bahwa nilai eigenvalues yang lebih dan 1,00 berjumlah 16 (enam belas) buah faktor sehingga dalam hal ini akan terdapat 16 (enam belas) komponen yang akan dibentuk oleh faktor yang akan dimasukkan ke dalam model untuk membentuk variabel.. Rotated Component Matrix, dapat diketahui bahwa terdapat 16 kelompok faktor yang nantinya akan membentuk variabel yang mempengaruhi keberhasilan prestasi belajar mata pelajaran IPS siswa kelas VII SMP Negeri 03 Kepanjen. Nampak bahwa terdapat 4 (dua) faktor yang gugur dan harus dikeluarkan dari model yaitu faktor X50, X51, X53, X54

\section{Analisis tahap 4}

Hasil pengujian ulang tahap ke-4, setelah tiga faktor tersebut dikeluarkan dari model dan dilakukan pengujian ulang. Nampak bahwa nilai KMO adalah 0,611 dan lebih besar dan 0,50 sehingga dapat dikatakan bahwa hasil analisis ini sudah tepat digunakan. Karena nilai KMO lebih dari 0,5 maka analisis faktor ini sudah tepat. Communalities, dimana nampak bahwa semua faktor nilainya lebih besar dari 0,50 sehingga dapat dikatakan bahwa faktor yang bersankutan cukup efektif. Total Variance Explained, dapat dilihat bahwa nilai eigenvalues yang lebih dari 1,00 berjumlah 15 (lima belas) buah faktor sehingga dalam hal ini akan terdapat 15 komponen yang akan dibentuk oleh faktor yang akan dimasukkan ke dalam model untuk membentuk variabel. Rotated Commponent Matrix, dapat dikatakan bahwa terdapat 15 kelompok faktor yang terbentuk. Nampak bahwa tidak ada faktor yang harus dikeluarkan karena kurang dari 0,50, sehingga analisis tidak diperlukan lagi. 
Dengan kata lain terdapat 15 faktor yang mempengaruhi keberhasilan prestasi belajar mata pelajaran IPS pada siswa kelas VII SMP Negeri 03 Kepanjen. Untuk lebih jelasnya dapat dilihat pada tabel berikut:

Tabel 4.2

Hasil Analisis Faktor (muatan faktor terdapat dilampiran 9 dalam Kolom Rotated Commponent Matrix)

\begin{tabular}{|c|c|c|c|c|}
\hline No & Nama Variabel & & $\begin{array}{l}\text { Muatan } \\
\text { Faktor }\end{array}$ & Nama Faktor \\
\hline 1. & $\begin{array}{l}\text { Suasana rumah } \\
\text { Motivasi orang tua } \\
\text { Kondisi tempat tinggal } \\
\end{array}$ & $\begin{array}{l}X 21 \\
\times 26 \\
\times 23 \\
\end{array}$ & $\begin{array}{l}0,844 \\
0,719 \\
0,638 \\
\end{array}$ & $\begin{array}{l}\text { Lingkungan } \\
\text { keluarga }\end{array}$ \\
\hline 2. & $\begin{array}{l}\text { Minat membaca buku } \\
\text { Keinginan menguasai materi } \\
\text { Kesulitan mengerjakan tugas }\end{array}$ & $\begin{array}{l}\mathrm{X} 12 \\
\mathrm{X} 8 \\
\mathrm{X} 5\end{array}$ & $\begin{array}{l}0,811 \\
0,541 \\
0,504\end{array}$ & Penguasaan materi \\
\hline 3. & $\begin{array}{l}\text { Kehadiran } \\
\text { Suasana kelas } \\
\text { Frekuensi keterlambatan masuk }\end{array}$ & $\begin{array}{l}\text { X39 } \\
\text { X44 } \\
\text { X41 }\end{array}$ & $\begin{array}{l}0,816 \\
0,731 \\
0,562\end{array}$ & Suasana kelas \\
\hline 4. & $\begin{array}{l}\text { Kelengkapan buku liteatur } \\
\text { Kepemilikan LKS } \\
\text { Jumlah buku wajib }\end{array}$ & $\begin{array}{l}\mathrm{X} 13 \\
\mathrm{X} 4 \\
\mathrm{X} 7\end{array}$ & $\begin{array}{l}0,756 \\
0,664 \\
0,389\end{array}$ & Sumber belajar \\
\hline 5. & $\begin{array}{l}\text { Keaktifan bertanya } \\
\text { Nilai pelajaran }\end{array}$ & $\begin{array}{l}\text { X30 } \\
\text { X19 }\end{array}$ & $\begin{array}{l}0,795 \\
0,479\end{array}$ & Keaktifan siswa \\
\hline 6. & $\begin{array}{l}\text { Frekuensi belajar setiap hari } \\
\text { Usaha memahami materi } \\
\text { Perhatian terhadap materi }\end{array}$ & $\begin{array}{l}\mathrm{X} 56 \\
\times 41 \\
\times 43 \\
\end{array}$ & $\begin{array}{l}0,768 \\
0,598 \\
0,507\end{array}$ & Minat belajar \\
\hline 7. & $\begin{array}{l}\text { Waktu belajar } \\
\text { Jam pelajaran } \\
\text { Sarana dan prasarana kelas }\end{array}$ & $\begin{array}{l}\mathrm{X} 17 \\
\mathrm{X} 14 \\
\mathrm{X} 3\end{array}$ & $\begin{array}{l}0,770 \\
0,710 \\
0,563\end{array}$ & $\begin{array}{l}\text { Lingkungan } \\
\text { sekolah }\end{array}$ \\
\hline 8. & $\begin{array}{l}\text { Waktu istirahat } \\
\text { Kondisi kesehatan }\end{array}$ & $\begin{array}{c}\text { X55 } \\
\text { X1 }\end{array}$ & $\begin{array}{l}0,764 \\
0,716 \\
\end{array}$ & Fisiologis siswa \\
\hline 9. & $\begin{array}{l}\text { Frekuensi pemberian tugas } \\
\text { Variasi dalam belajar }\end{array}$ & $\begin{array}{l}\text { X33 } \\
\text { X20 }\end{array}$ & $\begin{array}{l}0,380 \\
0,434\end{array}$ & Metode belajar \\
\hline 10. & $\begin{array}{l}\text { Keadaan lingkungan } \\
\text { Masyarakat }\end{array}$ & $\mathrm{X} 48$ & 0,775 & $\begin{array}{l}\text { Lingkungan } \\
\text { masyarakat }\end{array}$ \\
\hline 11. & Kehadiran guru & X34 & 0,487 & Kedisiplinan guru \\
\hline 12. & $\begin{array}{l}\text { Cara mengajar guru } \\
\text { Metode penyampaian guru }\end{array}$ & $\begin{array}{l}\mathrm{X} 15 \\
\mathrm{X} 46\end{array}$ & $\begin{array}{l}0,827 \\
0,626\end{array}$ & $\begin{array}{l}\text { Metode mengajar } \\
\text { guru }\end{array}$ \\
\hline 13. & $\begin{array}{l}\text { Ketepatan waktu } \\
\text { Mengkumpulkan tugas } \\
\text { Cara mengerjakan tugas }\end{array}$ & $\begin{array}{r}\text { X9 } \\
\times 35\end{array}$ & $\begin{array}{l}0,843 \\
0,425\end{array}$ & Kesiapan siswa \\
\hline 14. & Fasilitas belajar & $\mathrm{X} 52$ & 0,838 & Fasilitas belajar \\
\hline 15. & $\begin{array}{l}\text { Komposisi materi pelajaran } \\
\text { Ketelitian mengerjakan tugas } \\
\text { Tingkat kesulitan materi }\end{array}$ & $\begin{array}{l}X 49 \\
X 11 \\
X 47\end{array}$ & $\begin{array}{l}0,650 \\
0,411 \\
0,369\end{array}$ & Kurikulum \\
\hline
\end{tabular}




\section{KESIMPULAN}

Berdasarkan penelitian dan pembahasan terdapat 15 (lima belas) faktor yang mempengaruhi keberhasilan prestasi belajar mata pelajaran IPS pada siswa SMP Negeri 03 Kepanjen. (1) Lingkungan Keluarga, (2) Penguasaan materi, (3) Suasana kelas, (4) Sumber belajar, (5) keaktifan siswa, (6) Minat belajar, (7) Lingkungan sekolah, (8) fisiologis siswa, (9) Metode belajar, (10) Lingkungan Masyarakat, (11) Kedisiplinan guru, (12) Metode mengajar guru, (13) Kesiapan siswa, (14) Fasilitas belajar, (15) Kurikulum. Dimana faktor-faktor yang ada, faktor lingkungan merupakan faktor yang memberikan pengaruh paling besar terhadap keberhasilan prestasi belajar mata pelajaran IPS yang dicapai oleh siswa di SMP Negeri 03 Kepanjen yaitu memberikan pengaruh sebesar 17,21\%. Dengan demikian semakin tinggi dukungan yang diberikan dari lingkungan keluarga maka prestasi belajar yang di capai siswa juga akan semakin baik. Sedangkan faktor yang memberikan pengaruh paling kecil terhadap keberhasilan prestasi belajar mata pelajaran IPS yang dicapai oleh siswa SMP Negeri 03 Kepanjen adalah faktor Kurikulum sebesar 2,35\% apabila Kurikulum rendah maka akan memberikan pengaruh yang kecil terhadap prestasi belajar yang dicapai siswa

\section{DAFTAR PUSTAKA}

Arikunto. 2009. Prestasi Belajar. Jakarta: Bumi Aksara.

Dimyati dan Mudjiono. 2009. Pengertian Belajar. Jakarta: Rineka Cipta.

Djamarah. 2010. Pengertian Prestasi Belajar. Jakarta: Rineka Cipta.

Djamarah, Syaiful Bahri. 2008. Psikologi Belajar. Jakarta: Rineka Cipta.

Margono. 2010. Rancangan penelitian. Jakarta: Rineka Cipta.

Pusat Kurikulum Badan Penelitian Pengembangan Pendidikan Nasional. 2006. Model Pembelajaran

Terpadu IPS. Jakarta: Departemen Pendidikan Nasional [online] http://www.Depdiknas/ dari Volume 26.

Pusat Pengembangan PPL dan PKL. 2017. Pedoman PPL Universitas Kanjuruhan Malang

Syah. 2010. pengertian prestasi belajar. Jakarta : Rineka Cipta.

Slameto. 2010. Evaluasi Pendidikan. Jakarta: Bumi Aksara.

Slameto. 2010. Belajar dan Faktor-faktor yang Mempengaruhinya. Yogyakarta : Pustaka Belajar.

Sudjana, Nana. 2010. Metode Statistika. Bandung: Tarsito.

Sudjana, Nana.2009. Dasar- Dasar Proses Belajar Mengajar. Bandung: Sinar Baru.

Supranto, J. 2009. Analisis Multivariat Arti dan Interprestasi. Jakarta: PT. Rineka Cipta.

Sugiyono. 2014. Metode Penelitian Pendidikan Pendekatan Kuantitatif, Kualitatif, Dan R\&D. Bandung: Alfabeta.

Sugiyono. 2014. Metode penelitian kuantitatif, kualitatif, dan kombinasi (mixed methods), dan R\&D. Bandung: alfabeta.

Tu'u, Tulus. 2004. Peran Disiplin Pada Perilaku dan Prestasi Siswa. Jakarta: Gramedia Widiasarana Indonesia.

Undang-Undang Republik Indonesia No. 20 Tahun 2003. Tentang Sistem Pendidikan Nasional. 